\title{
O Pensamento CIENTÍFICO EM FÍSICA COMO TEMA DA EDUCAÇÃO BÁSICA
}

Luis Carlos de MENEZes ${ }^{1}$

$\mathrm{Na}$ educação brasileira, o aprendizado da física tem estado lamentavelmente pouco presente no ensino fundamental, de forma que a discussão da conceituação do pensamento científico em física como tema da educação básica pode, por enquanto, estar restrita ao ensino médio. Antes de mais nada, vale lembrar que, uma série de razões fazem a física escolar nesse nível em nada se parecer com a física da pesquisa científica, nem sequer com a física da engenharia e da tecnologia:

$>$ livros didáticos com conteúdos pseudo-acadêmicos estereotipados, que ostentam uma divisão inexplicada em tópicos disciplinares, um esquartejamento da ciência;

$>$ cursos que ignoram o desenvolvimento histórico da ciência ou, quando muito, apresentam, um tratamento meramente anedótico da evolução da física;

$>$ completa omissão da física quântica e relativista, cujos desenvolvimentos no século $\mathrm{XX}$, abriram espaço para a cosmologia e para a tecnologia contemporâneas;

\footnotetext{
'Professor da Universidade de São Paulo - USP.
} 
$>$ formação insuficiente dos professores nos aspectos técnicocientíficos, humanísticos e pedagógicos.

Diante desses aspectos críticos do pensamento científico ou da falta dele na escola, nos concentraremos numa caracterização ampla do que é o pensamento científico nessa ciência e das proposições no sentido de seu tratamento didático pedagógico, especificamente como conteúdo escolar.

Uma primeira consideração, para uma compreensão do pensamento científico, é de que, como construção humana, é algo histórico, ou seja, tem época e contexto, estando em articulação com os demais pensamentos e fazeres humanos de cada período e cultura. $\hat{E}$ sábio nesse sentido, para o ensino da física e para o das demais ciências, evitarem-se definições do tipo "ciência é...". Mesmo que tais definições não sejam ingênuas, mesmo quando são versões formais, para um público juvenil, das idéias popperianas, kuhnianas ou de outras escolas de pensamento, geralmente é de pouca utilidade a mera definição do pensamento científico, ou uma discussão de seu caráter, sem que o correspondente conhecimento científico possa ser efetivamente apreciado pelos alunos.

O filosofar sobre a ciência deveria estar associado à própria forma de se aprender a ciência, para os aspectos da modernidade científica, assim como a apresentação de visões clássicas deve ter seu papel pedagógico explicitado, evitando-se conscientemente as simplificações maniqueistas. Os pensamentos científicos da física grega e da medieval, por exemplo, são usualmente lembrados de forma caricatural, por conta de sua base experimental insuficiente, só para se apontar a notável "descoberta" da renascença, que é a ciência experimental. Isso tudo como parte de um programa de promoção publicitária de um famoso "método científico", uma panacéia insuperável, filha da genialidade de uns poucos, mãe de todas as tecnologias e inimiga mortal de todas as crendices, menos da própria, é claro!

Esquece-se, por exemplo, de apontar que a grande marca do pensamento teórico de alguns períodos da Grécia helênica, mais do que o eventual desapreço por verificações experimentais, é a busca de princípios gerais e permanentes que, expressando traços essenciais da natureza, da realidade sensível (Physis), constituam uma forma mais 
alta de saber, capaz de apreender o desígnio dos deuses em sua física (Physiké). Aliás, teoria (de Theos) é conhecimento divino, ainda que a física, que tem a ver com o corpóreo, perceptível, se anteponha à metafísica, ao que transcende os sentidos.

Esse sentido de universalidade, de procura permanente da coerência e da unidade explicativa é característica distintiva do pensamento científico até nossos dias. $O$ mesmo princípio da gravitação, que impõe a queda das pedras, deve mostrar que o vapor quente sobe, pois seria arbitrário e inaceitável a uma lei natural só valer em certas circunstâncias ou só para certos objetos. Mesmo não tendo prevalecido o sonho de Pitágoras, há dois e meio milênios, de reduzir as relações de proporção da natureza a razões entre números inteiros, o projeto pitagórico, num sentido ainda mais geral, de se encontrar uma lógica universal quantificável que abranja toda a realidade material, continua sendo até hoje -e talvez por muitos mais milênios- a característica fundante do pensamento científico em física.

Por essa mesma "herança grega", a física pode ser acompanhada como um grande jogo, o jogo da unificação explicativa que, por assim dizer, também contaminou as demais ciências. Nessa medida, a química se integra a esse jogo desde diversas teorias atômicas de diferentes épocas, a começar pela de outro grego, Demócrito. Só mais modernamente, contudo, com o advento da teoria quântica, a "lógica" das propriedades periódicas das substâncias químicas foi decifrada, e nem mesmo a biologia ficou a salvo, pois até mesmo a estereoquímica da vida foi explicada, com uma hélice dupla que codifica as informações genéticas e permite sua reprodução; surgiu assim a biologia molecular, com resultados notáveis que nos surpreendem a cada novo ano.

O pensamento moderno, que pode usar Descartes como referência, e que na física tem como marcos Galileu e Newton, além de consagrar a experimentação como critério de verdade, levou as ambições da ciência a um novo e alto patamar, ao submeter o Céu e a Terra às mesmas leis da mecânica e da gravitação e ao se descrever sistemas físicos, como o sistema solar, em termos de expressões analíticas de sua evolução no espaço e no tempo. O objetivo que a física passou a adotar, desde Newton, ou seja, conhecida uma configuração de objetos e o princípio de interação entre estes, 
determinar-se sua evolução, pode ser denominado de projeto newtoniano e, tanto quanto o projeto pitagórico, de certa forma também perdura até nossos dias. É claro que o que se apelidou de mecanicismo, não tardou a revelar seus limites de praticabilidade e de visão de mundo mas, em versões estatísticas e quânticas, ou em complexas articulações sistêmicas, a idéia de que o conhecimento físico, que inclui observação e elaboração de modelo, deve permitir a previsão de novos fenômenos e à determinação da evolução de sistemas físicos, se constitui em outra característica essencial do pensamento científico em física.

A termodinâmica, desenvolvida no século dezoito, especialmente com a sistematização das máquinas térmicas na primeira revolução industrial, assim como o eletromagnetismo, desenvolvido no século dezenove e de grande relevância para a segunda revolução industrial, associado aos motores elétricos, às lâmpadas incandescentes e, mais tarde, à eletrônica das telecomunicações, promoveram outras notáveis unificações conceituais, entre calor e movimento, entre fenômenos elétricos, magnéticos, ópticos, químicos, mecânicos e térmicos. Nestes dois séculos, além disso, confirmou-se outra marca permanente do pensamento científico em física que é a proximidade intrínseca entre o desenvolvimento da ciência e o dos processos tecnológicos, de interesse prático. Essa idéia de que há uma relação de gênese conjunta e reforço recíproco entre os conhecimentos científicos e os saberes técnicos, se consagra definitivamente com a relação entre a teoria quântica e terceira revolução industrial, com a microeletrônica dos semicondutores e dos lasers.

Nessas últimas considerações, parecem convergir traços aparentemente contraditórios da física, como a vocação para a universalidade, para a busca dos princípios gerais do mundo material e a intimidade com a tão efêmera esfera das coisas práticas das técnicas do fazer e do inventar, em que tudo é transitório. O pensamento científico na física vive efetivamente essa dialética entre o transiente e o permanente, entre a transformação e a conservação. De fato, e em plano menos alegórico, essa é a mais central de todas as suas características. A começar pelos seus mais fundamentais princípios de conservação, o da energia e os das quantidades de movimento, o 
conhecimento físico se constrói na procura das grandezas que se mantém constantes, em situações em que tudo parece estar variando.

Esses princípios estão também relacionados com outra marca essencial do pensamento científico em física. Eles são expressões "econômicas", que impõem a conservação de determinadas quantidades mas se foi percebendo, no entanto, que por detrás de cada princípio de conservação, sempre há uma condição de simetria: A homogeneidade e a isotropia do espaço correspondem às conservações das quantidades de movimento; a uniformidade no fluir do tempo corresponde à conservação da energia. A cada simetria, portanto, corresponde um princípio de conservação ou, noutras palavras, ao lado da economia, sempre está presente urna estética . A percepção dessa estética, não só nas simetrias explícitas do espaço e do tempo, mas também nas funções matemáticas da física clássica e da física quântica, é uma das mais importantes fontes de intuição na investigação do mundo natural, está presente em todos os campos da física e tem motivado notáveis descobertas. Pode-se assim afirmar que outra característica central do pensamento científico em física é a atenção para as simetrias, cuja revelação orienta a formulação de princípios de conservação.

Cabe aqui, como fecho dessas sugestões sobre como tratar no ensino escolar tais características gerais do pensamento científico: $E^{\prime}$ ao longo do aprendizado, ao ser tratado cada tópico da física, cada conceito, cada expressão matemática de cada princípio, que essas muitas características fundamentais do pensamento científico em física podem ser compreendidas de forma a dar mais sentido ao próprio processo educacional. Um discurso geral sobre elas, como aqui apresentado, pode servir ao educador, ao professor, ao formador de professores, ao avaliador, mas em hipótese alguma serve como tema em separado de aula regular, se não vier como coroamento dos tratamentos específicos. Seria algo perfeitamente inócuo se oferecido como mero apêndice de um curso em que o efetivo desenvolvimento desse pensamento científico não tiver ocorrido. 
